\title{
Electrochemical Behavior of Carbon Steel pre-Treated with an Organo Functional bis-Silane Filled with Copper Phthalocyanine
}

\author{
Patricia H. Suegama and Idalina V. Aoki*
}

\author{
Departamento de Engenharia Química, Escola Politécnica, Universidade de São Paulo, CP 61548, \\ 05424-970 São Paulo-SP, Brazil
}

\begin{abstract}
Neste trabalho, depositou-se sobre aço carbono o filme de bis-[trimetoxisililpropil]amina (BTSPA) adicionado de ftalocianina de cobre $(\mathrm{Cu}-\mathrm{Ph})$. Na obtenção desse filme variou-se as concentrações de $\mathrm{Cu}-\mathrm{Ph}$ e a temperatura de cura $\left(120\right.$ e $\left.150{ }^{\circ} \mathrm{C}\right)$ e nas amostras curadas à $150{ }^{\circ} \mathrm{C}$, adicionou-se uma segunda camada. $\mathrm{O}$ comportamento eletroquímico do aço carbono recoberto com o filme aditivado com $\mathrm{Cu}-\mathrm{Ph}$ foi estudado por técnicas eletroquímicas (medidas de espectroscopia de impedância eletroquímica e curvas de polarização) em solução aerada de $\mathrm{NaCl} 0,1 \mathrm{~mol} \mathrm{~L}^{-1}$. A caracterização física e química foi feita por análise termogravimétrica (TGA), microscopia eletrônica de varredura, medidas de ângulo de contato e espectroscopia de infravermelho. A TGA não mostrou decomposição da $\mathrm{Cu}-\mathrm{Ph}$ durante o processo de cura e a quantidade de $\mathrm{Cu}-\mathrm{Ph}$ adicionada ao filme polissilânico apresentou forte influência na resistência à corrosão, principalmente quando a amostra é curada a $150{ }^{\circ} \mathrm{C}$. Os resultados mostraram que menores concentrações de inibidor forneceram maior resistência à corrosão e a segunda camada aumentou em uma ordem de grandeza a resistência à corrosão.
\end{abstract}

The bis-[trimethoxysilylpropyl]amine (BTSPA) film filled with copper phthalocyanine $(\mathrm{Cu}-\mathrm{Ph})$ was prepared by adding different concentrations of copper phthalocyanine $-\mathrm{Cu}-\mathrm{Ph}$ and deposited on a carbon steel substrate using $120^{\circ} \mathrm{C}$ and $150{ }^{\circ} \mathrm{C}$ as curing temperatures. For samples cured at $150^{\circ} \mathrm{C}$ a second layer was also deposited. The electrochemical behavior of carbon steel coated with BTSPA filled with $\mathrm{Cu}-\mathrm{Ph}$ was studied by electrochemical measurements, electrochemical impedance spectroscopy (EIS) and polarization curves, in aerated $0.1 \mathrm{~mol} \mathrm{~L}^{-1} \mathrm{NaCl}$ solution. Physical and chemical characterization was made by thermogravimetric analysis (TGA), scanning electron microscopy, contact angle measurements and infrared spectroscopy. TGA showed no decomposition of $\mathrm{Cu}-\mathrm{Ph}$ during the curing process. $\mathrm{Cu}-\mathrm{Ph}$ added into the silane film showed a strong influence on its corrosion resistance, mainly when the samples are cured at $150^{\circ} \mathrm{C}$. The results showed that lower inhibitor concentrations led to a higher corrosion resistance and the second layer increased by one order of magnitude the corrosion resistance.

Keywords: corrosion, silane film, BTSPA, inhibitor

\section{Introduction}

Coupling agents are defined as materials that improve the adhesive bonds of dissimilar surfaces by increasing the interfacial adhesion, improving properties such as wettability, rheology, abrasion and catalytic inhibition, and strengthening of the boundary layers. ${ }^{1}$

Organofunctional silanes are hybrid organic-inorganic compounds that can be used as coupling agents across organic-inorganic interface. ${ }^{2}$ They may be used as adhesion

*e-mail: idavaoki@usp.br promoters between organic polymers and mineral substrates under a variety of circumstances. The silane adhesion promoters, or "coupling agents", may function as (i) a finish or surface modifier, (ii) a primer or (iii) an adhesive, depending on the thickness of the bonding material at the interface. A surface modifier or "finish" may theoretically be only a monomolecular layer, but in practice, may be several layers thick. ${ }^{2}$

Silane coatings are "passive" organic coatings, since they act essentially as a physical barrier that hinders the penetration of aggressive species towards the metallic substrate. However, this behaviour can be 
modified by the inclusion of small amounts of chemicals with corrosion inhibiting properties. ${ }^{1,2}$ Various organo functional silanes are available in the market today. Applied on different metallic substrates (as zinc, ${ }^{3,4}$ steel, ${ }^{5-7}$ aluminum, ${ }^{3,8,9}$ magnesium alloy ${ }^{10}$ ), they have been widely studied from both formation and performance points of view. ${ }^{11}$

A functional bis-silane, $\mathrm{X}_{3} \mathrm{Si}-\mathrm{Y}-\mathrm{SiX}_{3}$, is a compound where $\mathrm{Y}$ is a hydrocarbon chain which can also include a functional group. These silanes are hydrolyzed in a water/ alcohol mixture in which a sufficient number of silanol groups $(\mathrm{Si}-\mathrm{OH})$ are readly formed. These hydrophilic silanol groups are adsorbed when in contact with a clean metal surface leading to the formation of metallo-siloxane bonds. ${ }^{13,14}$

One of the ways to increase the corrosion performance of these silanes is to add corrosion inhibitors to the film, which can leach out slowly.

Ferreira et al. ${ }^{15}$ investigated silane and rare earth salts as chromate replacers for pre-treatments on galvanised steel and showed the two-step (immersion in rare earth followed by immersion in bis-[triethoxysilylpropyl]tetrasulphide BTESPT) pre-treatments resulted in good protection against corrosion. However, the best performance was obtained with lanthanum conversion coatings. This was observed either on uncoated and paint coated substrates. Silane (BTESPT) itself also showed some improved corrosion protection.

W. Trabelsi et al. ${ }^{12}$ studied the "passive" barrier properties of silane (BTESPT) coatings through doping with cerium nitrate or with zirconium nitrate. They showed that pre-treatments for galvanized steel substrates, based on BTESPT doped with amounts of cerium nitrate or zirconium nitrate, are much more protective than those based on nonmodified silane solutions. The beneficial effects of cerium are more important than those of zirconium.

V. Palanivel et al. ${ }^{13}$ studied the effects of addition of corrosion inhibitors (tolyltriazole, benzotriazole and cerium nitrate) to silane films in the performance of AA2024-T3 with $0.5 \mathrm{~mol} \mathrm{~L}^{-1} \mathrm{NaCl}$. They showed that silane films when loaded with organic or inorganic inhibitors also present the property of protecting fresh exposed metal. Silane films acted as inhibitor reservoir and released them into the solution where they migrated to damaged areas and protected metal from corrosion.

Organic corrosion inhibitors are promising candidates, as they appear to be easily compatible with hybrid coating material that can be loaded with inhibitors by adding the inhibitor into the hydrolysis solution prior to cross-linking and film formation. Corrosion inhibitors trapped within the coating material are leachable and active in the corrosive environment, making this doping procedure a simple and effective process for inhibitor storage and release. ${ }^{16}$

Aoki et al. ${ }^{17}$ verified the efficiency of copper phthalocyanine as a corrosion inhibitor for ASTM A606-4 steel in $16 \%$ hydrochloric acid, as well as, the degree of protection. Electrochemical measurements showed slight changes in open circuit potential and polarization curves showed that copper phthalocyanine acts as a mixed inhibitor for steel, and EIS measurements showed that inhibitor's efficiency is observed for increasing copper phthalocyanine ( $\mathrm{Cu}-\mathrm{Ph})$ concentrations.

The purpose of this study is to verify the influence of an inhibitor (copper phthalocyanine) concentration in a bis-[trimethoxysilylpropyl]amine (BTSPA) film by electrochemical methods and to characterize the film morphological and chemically in order to determine if this inhibitor can be used in association with the silane film in order to provide corrosion protection properties for carbon steel substrate.

\section{Experimental}

UNS 10100 steel with a nominal composition of 0.1 wt.\% C, 0.30 wt.\% Mn, 0.05 wt.\% S, 0.04 wt.\% P and balance of Fe was used as substrate. The steel substrate was degreased using an acetone ultrasonic bath for $10 \mathrm{~min}$ and then immersed in a $2.5 \% \mathrm{~m} / \mathrm{m} \mathrm{NaOH}$ solution also for $10 \mathrm{~min}$. The alkaline treatment helps to improve the wettability of the metallic substrate and to obtain a water break-free surface. Following alkaline treatment, the panels were rinsed with distilled water/ethanol or ketone and dried in a hot air stream. ${ }^{18}$

In an ethanol/deionised water (50/50) solvent at $\mathrm{pH} 4.0$ (adjusted with acetic acid) the bis-[trimethoxysilylpropyl] amine (BTSPA) (Figure 1A) was added forming a solution ( $2 \% \mathrm{~m} / \mathrm{m}$ silane $/ 98 \% \mathrm{~m} / \mathrm{m}$ solvent). It is worthy to stress the large water amount employed in the silane hydrolysis. The solution was stirred at room temperature for $30 \mathrm{~min}$ to allow hydrolysis occur. Copper phthalocyanine (Figure 1B) inhibitor was dissolved in the ethanol/deionised water solvent before the silane addition. Three groups of samples were obtained: (i) one immersion in hydrolysis solution (with $\mathrm{Cu}-\mathrm{Ph}$ ) and curing at $120^{\circ} \mathrm{C}$ for $40 \mathrm{~min}$; (ii) one immersion in hydrolysis solution (with $\mathrm{Cu}-\mathrm{Ph}$ ) and curing at $150{ }^{\circ} \mathrm{C}$ for $40 \mathrm{~min}$; (iii) one immersion in hydrolysis solution (with $\mathrm{Cu}-\mathrm{Ph}$ ) and curing at $150{ }^{\circ} \mathrm{C}$ for $20 \mathrm{~min}$, followed by another immersion in hydrolysis solution (without $\mathrm{Cu}-\mathrm{Ph}$ ) and curing at $150{ }^{\circ} \mathrm{C}$ for $40 \mathrm{~min}$.

All the conditions employed are in Table 1, where $\mathrm{S}=$ single layer, $\mathrm{D}=$ double layer; 120 or 150 are curing temperatures; and letters from $\mathrm{A}$ to $\mathrm{D}=$ increasing $\mathrm{Cu}-\mathrm{Ph}$ 
<smiles>CCO[Si](CCCNCCC[Si](OCC)(OCC)OCC)(OCC)OCC</smiles>

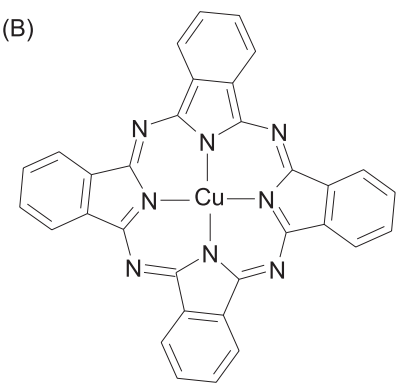

Figure 1. Schematic molecular structures of (A) bis-[trimethoxysilylpropyl] amine (BTSPA) and (B) copper phthalocyanine ( $\mathrm{Cu}-\mathrm{Ph})$.

concentration. The copper phtalocyanine concentrations used in this study were: (A) $1 \times 10^{-4}$, (B) $5 \times 10^{-4}$, (C) $1 \times 10^{-3}$ and (D) $5 \times 10^{-3} \mathrm{~mol} \mathrm{~L}^{-1}$ and $\mathrm{F}=\mathrm{BTSPA}$ film without $\mathrm{Cu}-\mathrm{Ph}$.

TGA analysis was performed in an oxidative atmosphere (air) with a linear temperature ramp. The maximum temperature was $800{ }^{\circ} \mathrm{C}, 10{ }^{\circ} \mathrm{C} \mathrm{min}-1$ heating rate and samples of approximately $10 \mathrm{mg}$ were used.

Contact angle was determined by the sessile drop method using a Ramé-Hart contact-angle goniometer, Model 100-10. Several measurements were carried out in the substrate with a water drop of $c a .15 \mathrm{~mm}^{3}$ under room atmosphere.
Surface characterization was made by a Philips XL-30 scanning electron microscope (SEM) coupled to an energy dispersive spectrometer analyzer (EDS). FTIR-RA measurements were obtained using a Bomem MB 100 spectrophotometer in the range from 4000 to $400 \mathrm{~cm}^{-1}$ with a spectral resolution of $4 \mathrm{~cm}^{-1}$.

Corrosion resistance of the coated steel was evaluated by electrochemical measurements of the samples in 400 $\mathrm{mL}$ of aerated and unstirred $0.1 \mathrm{~mol} \mathrm{~L}^{-1} \mathrm{NaCl}$ solution. An $\mathrm{Ag}|\mathrm{AgCl}| \mathrm{KCl}_{\text {sat }}$ electrode, connected to the working solution through a Luggin capillary, was used as reference and a Pt network as auxiliary electrode. Finally, a working electrode of each coated panel was mounted in the EG\&G electrochemical flat cell, exposing an area of $1 \mathrm{~cm}^{2}$ to the solution.

Electrochemical impedance (EIS) measurements were made using EG\&G Parc-283 potentiostat and a frequency response analyzer Solartron-SI1255. The EIS tests were performed applying $10 \mathrm{mV}$ (rms) to the stationary $\mathrm{E}_{\mathrm{OC}}$ value, starting from $5 \times 10^{4}$ to $5 \times 10^{-2} \mathrm{~Hz}$ and 7 measurements per frequency decade. Polarization curves were recorded for all samples in a potential range from -250 to $+250 \mathrm{mV}$ versus $\mathrm{E}_{\text {corr }} / \mathrm{Ag}|\mathrm{AgCl}| \mathrm{KCl}_{\text {sat }}$ at $0.5 \mathrm{mV} \mathrm{s}^{-1}$ scan rate.

\section{Results and Discussion}

\section{Reagent characterization}

Thermogravimetric analysis (TGA) is an analytical technique used to determine a material's thermal stability and its fraction of volatile components by monitoring the

Table 1. Conditions employed and parameters for coated steel samples

\begin{tabular}{|c|c|c|c|c|c|}
\hline Sample & $\begin{array}{l}\text { Immersion time in }[\mathrm{Cu}-\mathrm{Phcy}]+ \\
\text { BTSPA hydrolysis solution }\end{array}$ & $\begin{array}{l}{[\mathrm{Cu}-\mathrm{Phcy}] /} \\
\left(\mathrm{mol} \mathrm{L}^{-1}\right)\end{array}$ & $\begin{array}{l}1^{\text {st }} \text { Cure Temperature/ } \\
\text { time }\end{array}$ & $\begin{array}{l}\text { Immersion time in BTSPA } \\
\text { hydrolysis solution }\end{array}$ & $\begin{array}{l}2^{\text {nd }} \text { Cure Temperature/ } \\
\text { time }\end{array}$ \\
\hline S120A & $2 \min$ & $1 \times 10^{-4}$ & $120^{\circ} \mathrm{C} / 40 \mathrm{~min}$ & ------- & ------- \\
\hline S120B & $2 \min$ & $5 \times 10^{-4}$ & $120^{\circ} \mathrm{C} / 40 \mathrm{~min}$ & ------- & ------- \\
\hline $\mathrm{S} 120 \mathrm{C}$ & $2 \min$ & $1 \times 10^{-3}$ & $120^{\circ} \mathrm{C} / 40 \mathrm{~min}$ & ------- & ------- \\
\hline S120D & $2 \mathrm{~min}$ & $5 \times 10^{-3}$ & $120^{\circ} \mathrm{C} / 40 \mathrm{~min}$ & ------- & ------ \\
\hline S120F & $2 \mathrm{~min}$ & ------ & $120^{\circ} \mathrm{C} / 40 \mathrm{~min}$ & ------ & ------- \\
\hline S150A & $2 \min$ & $1 \times 10^{-4}$ & $150^{\circ} \mathrm{C} / 40 \mathrm{~min}$ & ------- & ------- \\
\hline S150B & $2 \mathrm{~min}$ & $5 \times 10^{-4}$ & $150^{\circ} \mathrm{C} / 40 \mathrm{~min}$ & ------- & ------- \\
\hline $\mathrm{S} 150 \mathrm{C}$ & $2 \min$ & $1 \times 10^{-3}$ & $150^{\circ} \mathrm{C} / 40 \mathrm{~min}$ & ------- & ------- \\
\hline S150D & $2 \min$ & $5 \times 10^{-3}$ & $150^{\circ} \mathrm{C} / 40 \mathrm{~min}$ & ------- & ------- \\
\hline $\mathrm{S} 150 \mathrm{~F}$ & $2 \min$ & ------- & $150^{\circ} \mathrm{C} / 40 \mathrm{~min}$ & ------ & ------- \\
\hline D150A & $2 \min$ & $1 \times 10^{-4}$ & $150^{\circ} \mathrm{C} / 20 \mathrm{~min}$ & $2 \min$ & $150^{\circ} \mathrm{C} / 40 \mathrm{~min}$ \\
\hline D150B & $2 \min$ & $5 \times 10^{-4}$ & $150^{\circ} \mathrm{C} / 20 \mathrm{~min}$ & $2 \min$ & $150^{\circ} \mathrm{C} / 40 \mathrm{~min}$ \\
\hline D150C & $2 \min$ & $1 \times 10^{-3}$ & $150^{\circ} \mathrm{C} / 20 \mathrm{~min}$ & $2 \min$ & $150^{\circ} \mathrm{C} / 40 \mathrm{~min}$ \\
\hline D150D & $2 \min$ & $5 \times 10^{-3}$ & $150^{\circ} \mathrm{C} / 20 \mathrm{~min}$ & $2 \min$ & $150^{\circ} \mathrm{C} / 40 \mathrm{~min}$ \\
\hline D150F & $2 \min$ & ------- & $150^{\circ} \mathrm{C} / 20 \mathrm{~min}$ & $2 \min$ & $150^{\circ} \mathrm{C} / 40 \mathrm{~min}$ \\
\hline
\end{tabular}


weight change that occurs as a specimen is heated. It is commonly employed in research and testing to determine characteristics of materials such as polymers, to determine degradation temperatures, absorbed moisture content of materials, level of inorganic and organic components in materials, decomposition points of explosives, and solvent residues. It is often used to estimate corrosion kinetics in high temperature oxidation. This technique measures changes in weight of a sample with increasing temperature. Moisture content and presence of volatile species can be determined by this technique. ${ }^{19}$ In order to observe if the $\mathrm{Cu}-\mathrm{Ph}$ is stable at curing temperature, thermogravimetric analyses (TGA) measurement were done to pure $\mathrm{Cu}-\mathrm{Ph}$ and pure BTSPA silane and are presented in Figure 2.

Figure 2 shows the stability of $\mathrm{Cu}-\mathrm{Ph}$ until $\mathrm{ca} .450^{\circ} \mathrm{C}$, and then the curing temperature is not able to produce its degradation. TGA of BTSPA shows a high decrease of weight at temperature lower than $150{ }^{\circ} \mathrm{C}$, attributed to water loss, in agreement with condensation process to form $\mathrm{Si}-\mathrm{O}-\mathrm{Si}$ bonds. As can be seen, at $100^{\circ} \mathrm{C}$, water not retained into the film is lost, and then a $120^{\circ} \mathrm{C}$ temperature was used with the aim to minimize the final process cost and a higher temperature $\left(150^{\circ} \mathrm{C}\right)$ was also studied. Both temperatures were chosen to observe the cost/benefit relation in the crosslinking process.

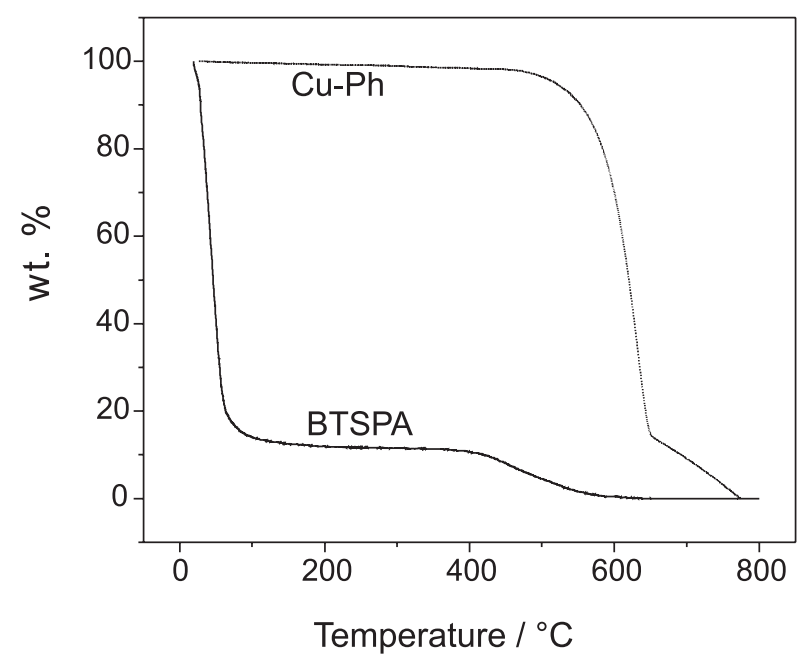

Figure 2. TGA curves of $\mathrm{Cu}-\mathrm{Ph}$ and BTSPA.

\section{Film characterization}

S120F and S120A (lowest Cu-Ph concentration) coated samples FTIR-RA spectra (reflection/absorption Fourier transform infrared spectroscopy) and absorption spectrum for pure $\mathrm{Cu}-\mathrm{Ph}$ peaks indicate that the characteristic $\mathrm{Cu}-\mathrm{Ph}$ peaks are not shifted when added to the film as in Figure $3 \mathrm{~A}$, indicating that $\mathrm{Cu}-\mathrm{Ph}$ does not present significant chemical interaction with the BTSPA, even for higher $\mathrm{Cu}-\mathrm{Ph}$ concentrations as in $\mathrm{S} 150 \mathrm{D}$ sample (Figure $3 \mathrm{~b}$ ). The detailed attribution of peaks of the phthalocyanine skeleton is found in the literature. ${ }^{20,21} \mathrm{Cu}-\mathrm{Ph}$ particles are dragged by the silane solution that wets the steel surface, and when the sample is cured, ethanol and water volatilize and the copper phthalocyanine is fixed in the lattice formed by the silane reticulation during the curing process.

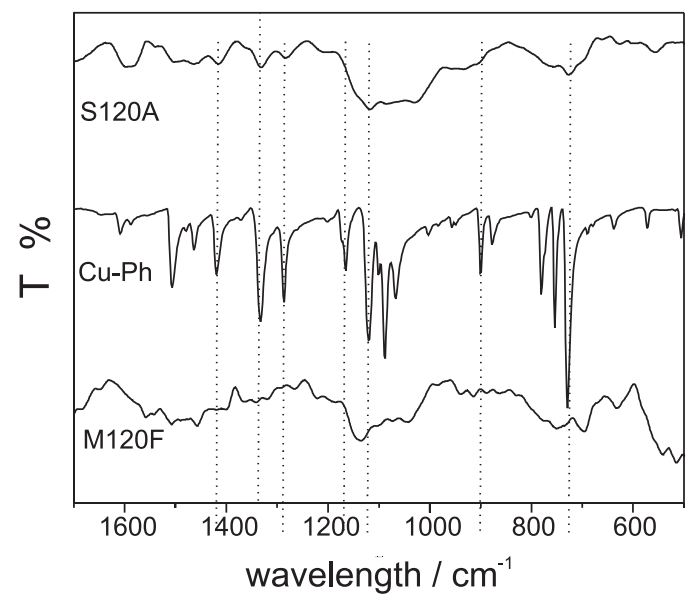

(A)

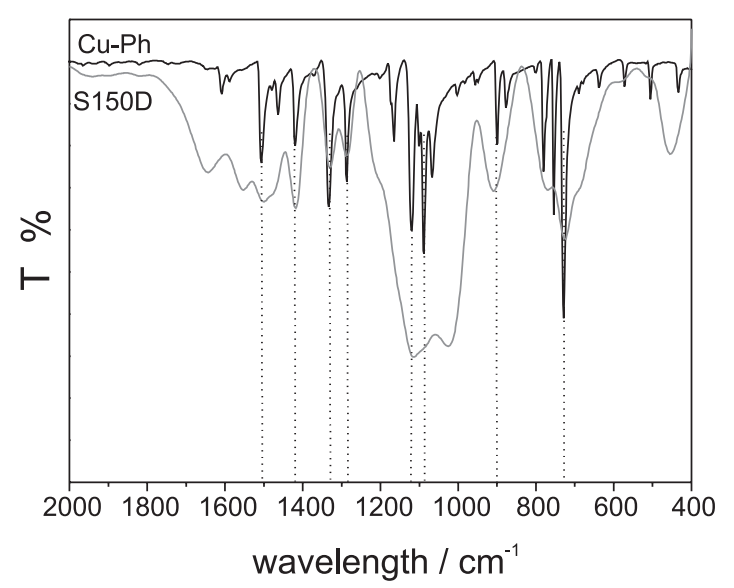

(B)

Figure 3. FTIR-RA spectra of (A) S120F, S120A samples and (B) S150D sample and absorption IR spectra of pure $\mathrm{Cu}-\mathrm{Ph}$.

Figure 4 presents the absorption IR spectra of pure polymerized BTSPA after curing at $120^{\circ} \mathrm{C}$ and $150{ }^{\circ} \mathrm{C}$ for $40 \mathrm{~min}$ and in Table 2, the main peaks are described. $\mathrm{Si}-\mathrm{O}-\mathrm{Si}$ peaks appear between $1,130-1,000 \mathrm{~cm}^{-1}$ and Si-O-H at 900-950 $\mathrm{cm}^{-1}$. A more intense peak at $1,110 \mathrm{~cm}^{-1}$, atributted to $\mathrm{SiOSi}$ indicates a denser siloxane network at samples obtained at $150{ }^{\circ} \mathrm{C}$ than at $120{ }^{\circ} \mathrm{C}$ curing temperature. ${ }^{24}$ The presence of an intense band in $1,130 \mathrm{~cm}^{-1}$ is related with the formation of $\mathrm{Si}-\mathrm{O}-\mathrm{Si}$ bonds that impart to the film a protective effect for the substrate, which can 
be observed by EIS measurements. The peak at 1,600 $\mathrm{cm}^{-1}$ evidences the presence of the amine group $\left(\mathrm{NH}_{2}\right)$ and at $3,600 \mathrm{~cm}^{-1}$ a band due to N-H stretching can be observed.

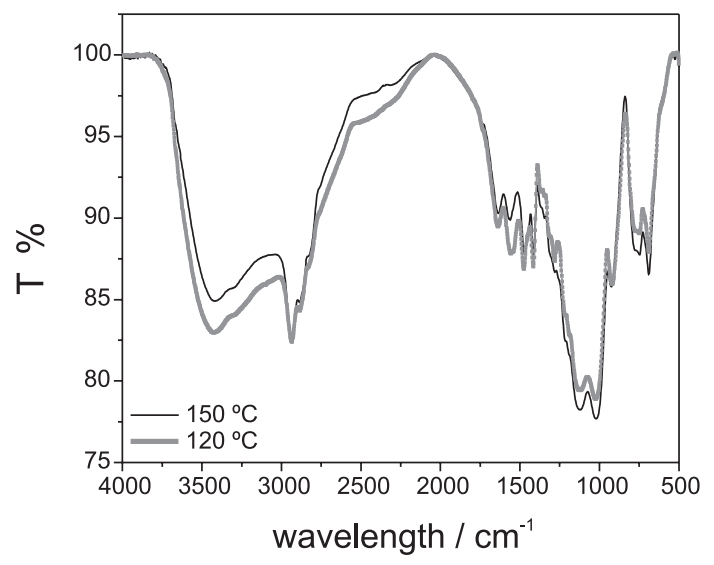

(A)

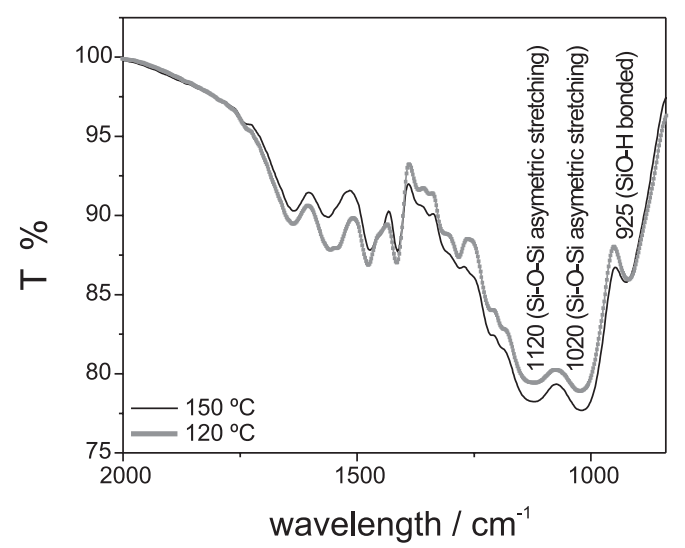

(B)

Figure 4. Absorption IR spectra of pure polymerized BTSPA (it is not a film) cured at $120^{\circ} \mathrm{C}$ and $150{ }^{\circ} \mathrm{C}$ : (A) from 500 to $4,000 \mathrm{~cm}^{-1}$ and (B) from 750 to $2,000 \mathrm{~cm}^{-1}$.

Table 2. Absorption region and bond type found in silanes ${ }^{21,22}$

\begin{tabular}{ll}
\hline Wavelength $/ \mathrm{cm}^{-1}$ & Bond type \\
\hline $700-800$ & $\mathrm{C}-\mathrm{H}\left(\mathrm{Si}-\mathrm{CH}_{2}-\mathrm{CH}_{2}-\mathrm{Si}\right)$ stretching vibrations \\
$860-760$ & $\mathrm{Si}-\mathrm{C}$ stretching \\
$890-920$ & $\mathrm{Si}-\mathrm{O}(\mathrm{Si}-\mathrm{OH})$ stretching vibrations \\
$900-960$ & $\mathrm{Si}-\mathrm{O}-\mathrm{C}_{2} \mathrm{H}_{5}$ vibrations \\
$1,130-1,000$ & $\mathrm{Si}-\mathrm{O}-\mathrm{Si}$ asymmetric stretching \\
$1,250-1,200$ & $\mathrm{Si}^{-} \mathrm{CH}_{2}-\mathrm{R}$ deformation $_{1}$ \\
$1,300-1,400$ & $\mathrm{CH}_{2}$ and $\mathrm{CH}_{3}$ bending vibrations \\
$1,575-1,600$ & $\mathrm{~N}-\mathrm{H}\left(\mathrm{NH}_{2}\right)$ bending vibrations \\
$1,700-1,750$ & $\mathrm{C}=\mathrm{O}($ acetic acid$)$ stretching vibrations \\
$2,900-3,000$ & $\mathrm{C}-\mathrm{H}\left(\mathrm{CH}_{2}\right.$ and $\mathrm{CH}$ ) stretching vibrations \\
$3,200-3,700$ & $\mathrm{OH}$ (from $\mathrm{Si}-\mathrm{OH}$ group or $\left.\mathrm{H}_{2} \mathrm{O}\right)$ stretching \\
& vibrations \\
$3,400-3,700$ & $\mathrm{~N}-\mathrm{H}$ stretching vibrations \\
\hline
\end{tabular}

At $2,900 \mathrm{~cm}^{-1}$ the peak of $\mathrm{C}-\mathrm{H}$ stretching $\left(\mathrm{CH}_{2}\right.$ and $\left.\mathrm{CH}_{3}\right)$ can be found.

Figure 4A shows the band at $3,000-3,500 \mathrm{~cm}^{-1}$ which is attributed to $\mathrm{O}-\mathrm{H}$ bond, that can be related to water, ethanol and/or silanol group, but it is possible to observe a decrease of this band with the increase of the curing temperature, and at $1,000-1,100 \mathrm{~cm}^{-1}$ the reverse can be seen, indicating that there are more $\mathrm{Si}-\mathrm{O}-\mathrm{Si}$ bonds at $150{ }^{\circ} \mathrm{C}$.

The peak at $925 \mathrm{~cm}^{-1}$, in Figure $4 \mathrm{~B}$ is attributed to remaining $\mathrm{Si}-\mathrm{O}-\mathrm{H}$ group not involved during the reticulation of the silane. It can be seen that the peaks at $925 \mathrm{~cm}^{-1}$ for cured film at 120 and $150^{\circ} \mathrm{C}$ present almost equal intensity, as a response with similar effect of temperature and time of curing in the consumption of $\mathrm{Si}-\mathrm{OH}$ groups, taking into account the small difference between the two curing temperatures for silane films. ${ }^{24}$

Doublet peaks at $1,350 \mathrm{~cm}^{-1}$ and $1,450 \mathrm{~cm}^{-1}$ is attributed to the formation of ammonium acetate ${ }^{24}$ and another doublet at $1,500-1,600 \mathrm{~cm}^{-1}$ is attributed to $\mathrm{O}-\mathrm{H}$ stretching in the ethanol of solvent. All these peaks diminish in intensity for higher curing temperature indicating the withdrawn of ethanol and water during the film curing besides the formation of $\mathrm{COO}^{-}$ions by reaction of secondary groups and acetic acid. All these phenomena occur simultaneously, and it is impossible to distinguish them.

Figure 5 shows SEM images of S120A, S120D samples and pure $\mathrm{Cu}-\mathrm{Ph}$ deposited on substrate. Figure $5 \mathrm{~A}$ shows a homogeneous surface, where $\mathrm{Cu}-\mathrm{Ph}$ is dissolved into the film. In Figure 5B, it is possible to observe that $\mathrm{Cu}-\mathrm{Ph}$ does not interact with the film, being only physically retained on the surface by the silane film. Comparing Figure 5A and $5 \mathrm{~B}$, in which a high quantity of copper phthalocyanine is added, it is possible to see that the silane film cannot cover all inhibitor particles and cracks appear in the silane film on the top of $\mathrm{Cu}-\mathrm{Ph}$ when the sample is submitted to the curing process. Cracks are formed by curing process due to the water/ethanol loss and siloxane bonding formation that stretch out on the surface. These defects in the film for high concentration of $\mathrm{Cu}-\mathrm{Ph}$ can facilitate the electrolyte permeation and consequently attack the substrate. The same occurred for S150 series.

A possible relation of the protection against corrosion supplied by the film to the substrate can be established with the hydrophobic character of the sample surface. Then, contact angle was measured and obtained data are shown in Table 3 (results are the average value for measurements conducted on different sites of a given coated steel plate).

Contact angle is the angle at which a liquid/vapor interface meets the solid surface. Contact angle is specific for any given system and is determined by interactions 


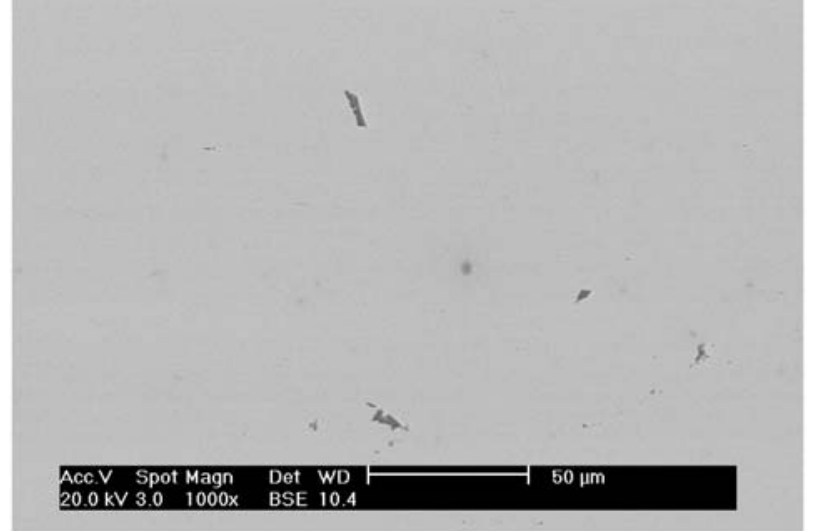

(A)

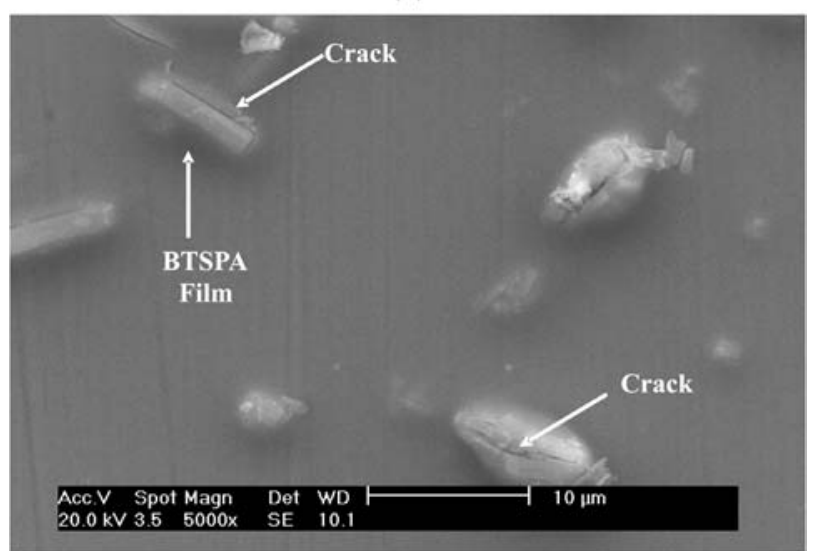

(B)

Figure 5. SEM image of (A) S120A, (B) S120D.

Table 3. Results of the contact angle measurements conducted sn silane coated carbon steel samples

\begin{tabular}{|c|c|c|c|c|c|c|c|}
\hline \multicolumn{2}{|c|}{ M120A } & \multicolumn{2}{|c|}{ M120B } & \multicolumn{2}{|c|}{ M120C } & \multicolumn{2}{|c|}{ M120D } \\
\hline $\mathrm{R}^{1}$ & $\mathrm{~L}^{2}$ & $\mathrm{R}^{1}$ & $\mathrm{~L}$ & $\mathrm{R}^{1}$ & $\mathrm{~L}$ & $\mathrm{R}^{1}$ & $\mathrm{~L}$ \\
\hline $86 \pm 1$ & $87 \pm 1$ & $79 \pm 1$ & $79 \pm 1$ & $60 \pm 1$ & $60 \pm 1$ & $61 \pm 1$ & $61 \pm 2$ \\
\hline \multicolumn{8}{|c|}{${ }^{1}=$ right side ${ }^{2}=$ left side.} \\
\hline \multicolumn{2}{|c|}{ M150A } & \multicolumn{2}{|c|}{ M150B } & \multicolumn{2}{|c|}{ M150C } & \multicolumn{2}{|c|}{ M150D } \\
\hline $\mathrm{R}^{1}$ & $\mathrm{~L}^{2}$ & $\mathrm{R}^{1}$ & $\mathrm{~L}^{2}$ & $\mathrm{R}^{1}$ & $\mathrm{~L}^{2}$ & $\mathrm{R}^{1}$ & $\mathrm{~L}^{2}$ \\
\hline $83 \pm 1$ & $81 \pm 1$ & $75 \pm 1$ & $74 \pm 1$ & $70 \pm 1$ & $70 \pm 1$ & $68 \pm 1$ & $69 \pm 1$ \\
\hline \multicolumn{8}{|c|}{${ }^{1}=$ right side ${ }^{2}=$ left side.} \\
\hline \multicolumn{2}{|c|}{ D150A } & \multicolumn{2}{|c|}{ D150B } & \multicolumn{2}{|c|}{ D150C } & \multicolumn{2}{|c|}{ D150D } \\
\hline $\mathrm{R}^{1}$ & $\mathrm{~L}^{2}$ & $\mathrm{R}^{1}$ & $\mathrm{~L}^{2}$ & $\mathrm{R}^{1}$ & $\mathrm{~L}^{2}$ & $\mathrm{R}^{1}$ & $\mathrm{~L}^{2}$ \\
\hline $76 \pm 1$ & $74 \pm 1$ & $86 \pm 2$ & $85 \pm 2$ & $83 \pm 1$ & $82 \pm 1$ & $70 \pm 1$ & $71 \pm 1$ \\
\hline \multicolumn{8}{|c|}{${ }^{1}=$ right side ${ }^{2}=$ left side } \\
\hline \multicolumn{3}{|c|}{ M120F } & \multicolumn{2}{|c|}{ M150F } & \multicolumn{3}{|c|}{$\mathrm{D} 150 \mathrm{~F}$} \\
\hline $\mathrm{R}^{1}$ & $\mathrm{~L}$ & $2^{2}$ & $\mathrm{R}^{1}$ & $\mathrm{~L}^{2}$ & & $\mathrm{R}^{1}$ & $\mathrm{~L}^{2}$ \\
\hline $69 \pm 1$ & 69 & \pm 2 & $75 \pm 1$ & $74 \pm 1$ & & $5 \pm 1$ & $76 \pm 1$ \\
\hline
\end{tabular}

${ }^{1}=$ right side ${ }^{2}=$ left side. across the three interfaces. A wettable surface may also be termed hydrophilic and a non-wettable surface, hydrophobic..$^{25}$ On extremely hydrophilic surfaces, a water droplet will completely spread (an effective contact angle of $0^{\circ}$ ). This occurs for surfaces that have a large affinity with water (including materials that adsorb water). On many hydrophilic surfaces, water droplets will exhibit contact angles from $10^{\circ}$ to $30^{\circ}$. On highly hydrophobic surfaces, which are incompatible with water, one observes a large contact angle $\left(70^{\circ}\right.$ to $\left.90^{\circ}\right)$. Contact angle thus, directly provides information on the interaction energy between the surface and the liquid. ${ }^{25,26} \mathrm{~A}$ contact angle of $90^{\circ}$ or greater generally characterizes a surface as not-wettable, and angles lower than $90^{\circ}$ means that the surface can be wettable at some extent.

Contact angle values for S120 series showed a higher hydrophobicity for samples with lowest copper phthalocyanine concentration, so it was expected that this sample presented a higher barrier effect than did others, promoting a greater corrosion resistance (which was confirmed by electrochemical measurements). Contact angle measurements for $\mathrm{S} 150$ and for D150 series showed higher values for samples S150A and D150B, respectively, indicating that these samples present higher hydrophobic surfaces. Comparing the curing process at $120^{\circ} \mathrm{C}$ and $150^{\circ} \mathrm{C}$ it is possible to observe that samples cured at $150^{\circ} \mathrm{C}$ present a higher contact angle values. Contact angle measurements are more sensitive to the number of $\mathrm{Si}-\mathrm{OH}$ hydrophilic groups on the surface in comparison to IR analysis.

\section{Electrochemical characterization}

Electrochemical impedance spectroscopy (EIS) experiments were performed at the stabilized open-circuit potential, $\mathrm{E}_{\mathrm{OC}}$. Nyquist plot for bare carbon steel (Figure 6) shows a capacitive semicircle that is close to $2 \mathrm{k} \Omega$ and is the lowest value measured among the studied systems.

EIS diagrams of S120 series obtained after $1 \mathrm{~h}$ of immersion (data not presented) showed an increase in the inhibitor concentration in the hydrolysis solution reducing the diameter of the capacitive arcs of the silane coated samples; samples with a higher amount of $\mathrm{Cu}-\mathrm{Ph}$ provided lower protection to the steel substrate due to the presence of cracks in the film caused by the large amount of particles of $\mathrm{Cu}-\mathrm{Ph}$ retained in the film. Silane coated samples with $1 \times 10^{-4} \mathrm{~mol} \mathrm{~L}^{-1}$ of $\mathrm{Cu}-\mathrm{Ph}$ performed much better in terms of corrosion resistance as compared with pure BTSPA film or BTSPA filled with higher $\mathrm{Cu}-\mathrm{Ph}$ concentrations. The highest total impedance obtained for S120 series was about $12 \mathrm{k} \Omega$, that is lower than the values obtained for $S 150$ and D150 series. Comparing S120 and S150 series, S150 


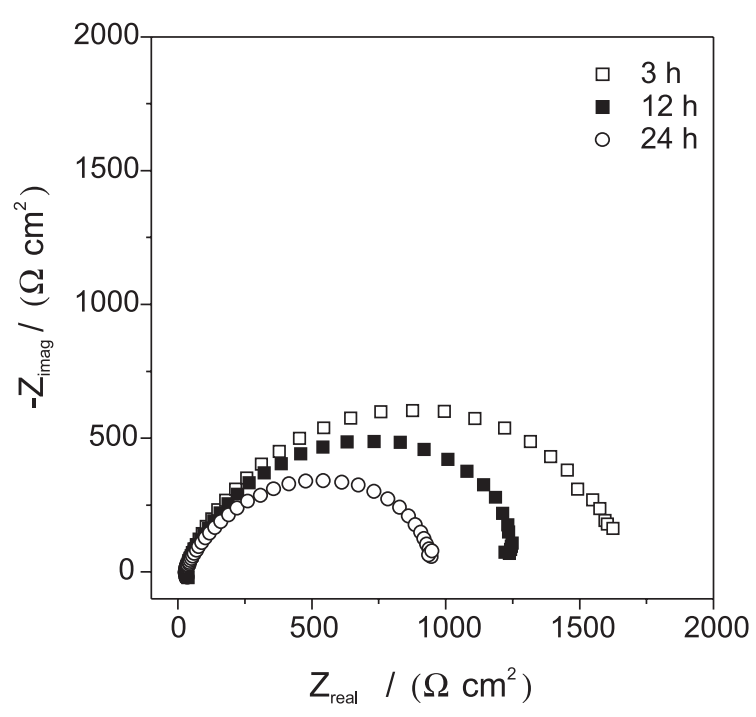

Figure 6. Nyquist plots for carbon steel substrate obtained after 3, 12 and $24 \mathrm{~h}$ of immersion in $0.1 \mathrm{~mol} \mathrm{~L}^{-1} \mathrm{NaCl}$ solution.

series presents total resistance higher than $\mathrm{S} 120$ series due to a better reticulation of the film at $150{ }^{\circ} \mathrm{C}$, which can be confirmed by IR analysis (more intense peak at $1,100 \mathrm{~cm}^{-1}$ due to $\mathrm{Si}-\mathrm{O}-\mathrm{Si}$ ).

Figure 7 shows Nyquist and Bode plots for S150 series after 3, 12 and $24 \mathrm{~h}$ of immersion. It can be observed that the polarization resistance and at least two time constants, the first one attributed to the silane film, appears at high frequencies and the second time constant at low frequencies is attributed to the substrate oxidation.

After $3 \mathrm{~h}$ immersion, S150A and S150B samples (Figures 7A and 7B) present two well defined time constants and for S150C and S150D samples (Figures 7C and 7D) the constants are overlapped, indicating that theses samples can be easily attacked by the electrolyte. S150A and S150B samples show high total impedance for the first $3 \mathrm{~h}$ of immersion and a decrease after $12 \mathrm{~h}$ and $24 \mathrm{~h}$. High total impedance measured after $3 \mathrm{~h}$ immersion should be related to the hydrophobic surface and to the good quality film reticulation formed in the electrode surface as a consequence of higher temperature used in the curing process. For longer immersion times, the total impedance values decreased, probably due to the electrolyte penetration into the film reaching the substrate. These results clearly indicate that the film and its surface, and film/substrate interface degrade as the immersion time increases. This fact can be observed clearly by Bode phase angle plots, in which time constant, attributed to the film, at high frequencies shifts to low frequencies and the second time constant, attributed to the substrate, at low frequencies shifts to higher frequencies. Bode phase angle plots show that longer immersion time had the maximum increment at intermediary frequencies $(c a .1-10 \mathrm{~Hz})$ which is better defined while the one at higher frequency (attributed to the film) almost disappears.

Bode phase angle plots of S150C and S150D samples, do not show a well defined separation between time constants, the constants are already overlapped showing that the electrolyte reach the substrate easily because of cracks created during the curing process.

The sample that presented higher total impedance was S150A followed by S150B $>$ S150C $>$ S150D, indicating that a higher amount of $\mathrm{Cu}-\mathrm{Ph}$ increases stress and cracks in the film.

Figure 8 shows EIS data for D150 series and the same process observed for $\mathrm{S} 150$ series was also observed for D150 series. However, the total impedance increased one order of magnitude and a delay in the electrolyte attack to the substrate was observed to all coated samples. Time shift constants in the Bode phase angle plots were also observed but at lower intensity. D150 series resists more than $72 \mathrm{~h}$ with total impedance values higher than $15 \mathrm{k} \Omega \mathrm{cm}^{2}$, while $\mathrm{S} 150$ series after $24 \mathrm{~h}$ already presented values lower than $15 \mathrm{k} \Omega \mathrm{cm}^{2}$. These data indicate the second layer can improve the corrosion resistance and it can be due to the fact that the second layer covers the cracks, decreasing the defects, and/or the second curing process improves a better reticulation of the first layer.

Figure 8 allows observing much higher total impedance values $\left(100 \mathrm{k} \Omega \mathrm{cm}^{2}\right)$ than any other series, indicating a better protection provided to the substrate with a double layer of silane when compared to only a single layer. Comparing the capacitive arcs of samples, D150B (Figure 8B) and D150C (Figure 8C) samples presented highest total impedance values after $3 \mathrm{~h}$ immersion, and comparing both, D150B presented a larger capacitive arc than did D150C sample. These facts can be attributed to: in D150A sample the inhibitor concentration is very low, then, it lacks for inhibitor; and in D150D sample $\mathrm{Cu}-\mathrm{Ph}$ concentration is very high, then there are a lot of defects that are not totally coated by the second layer. In D150B and D150C samples, an intermediary inhibitor concentration increases the resistance against chloride ions, because it has enough inhibitor and the second layer minimizes the defects caused by $\mathrm{Cu}-\mathrm{Ph}$ particles during the curing process.

The second layer covers the first layer, and then it is possible to increase the $\mathrm{Cu}-\mathrm{Ph}$ concentration into the film, because the second layer will cover the defects, closing the cracks previously present in the first layer.

Figure 9 presents one polarization curve for each condition (samples that presented the best results from each 

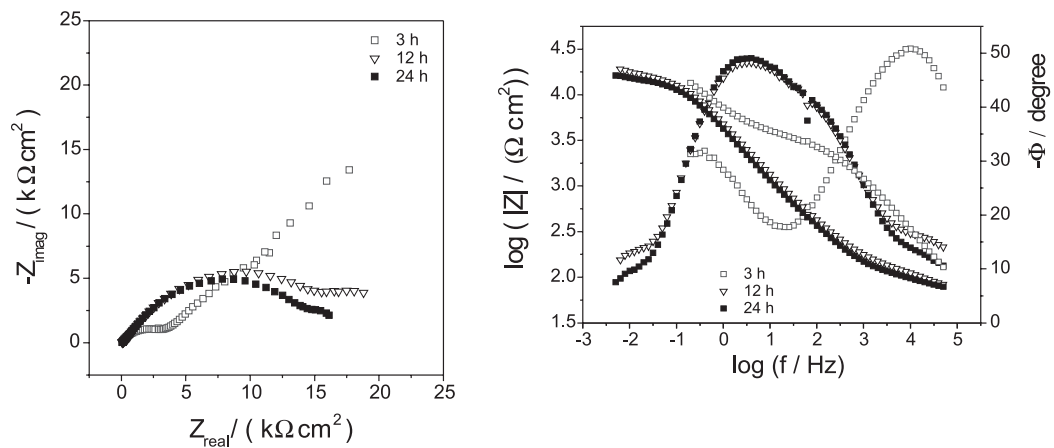

(A)
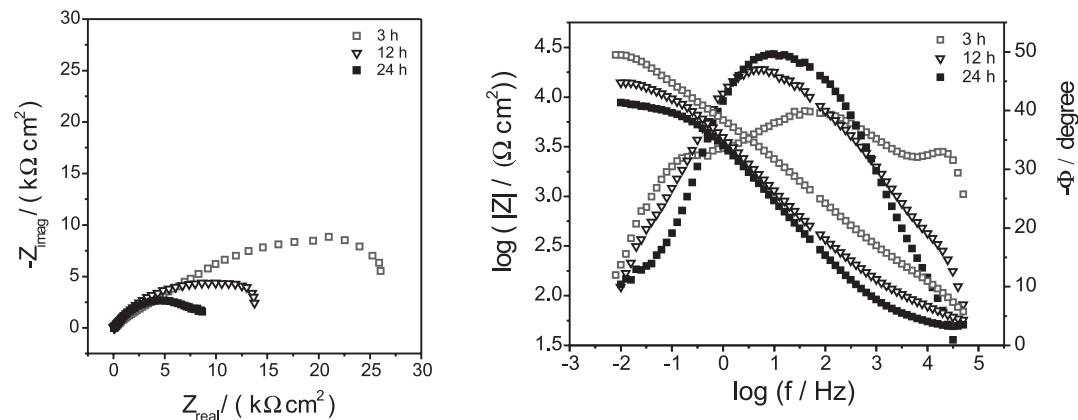

(B)
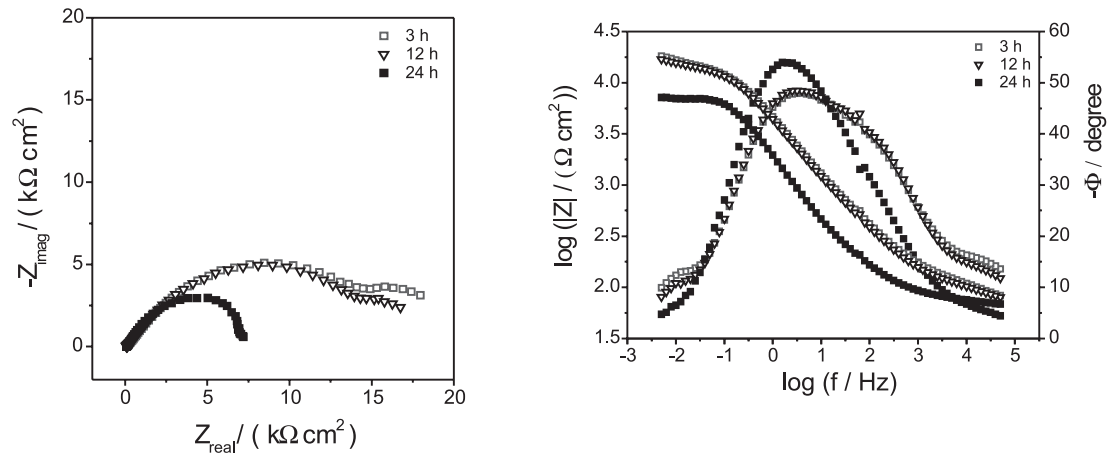

(C)
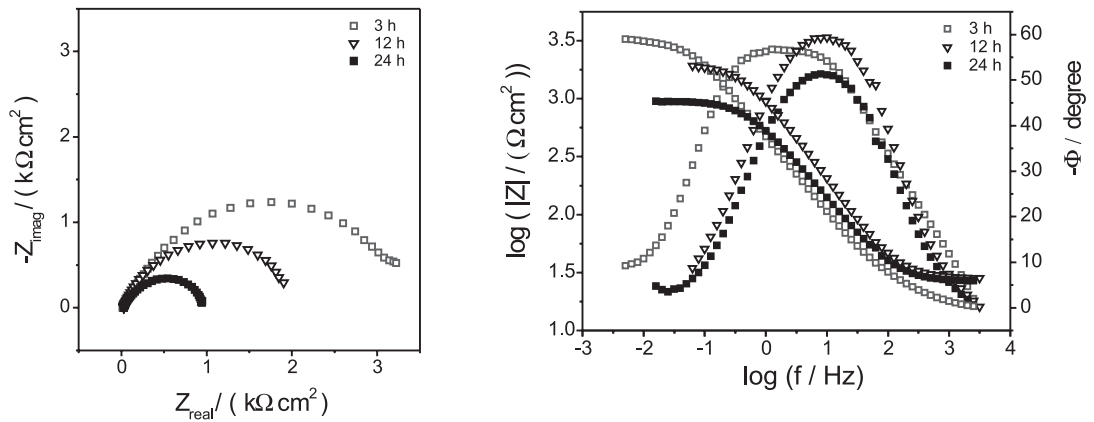

(D)

Figure 7. EIS diagrams for S150 series, Nyquist plots and $\log |\mathrm{Z}|$ and - $\phi$ vs. $\log (\mathrm{f})$ Bode plots for (A) S150A (B) S150B, (C) S150C and (D) S150C samples obtained after 3,12 and $24 \mathrm{~h}$ of immersion in $0.1 \mathrm{~mol} \mathrm{~L}^{-1} \mathrm{NaCl}$ solution. 

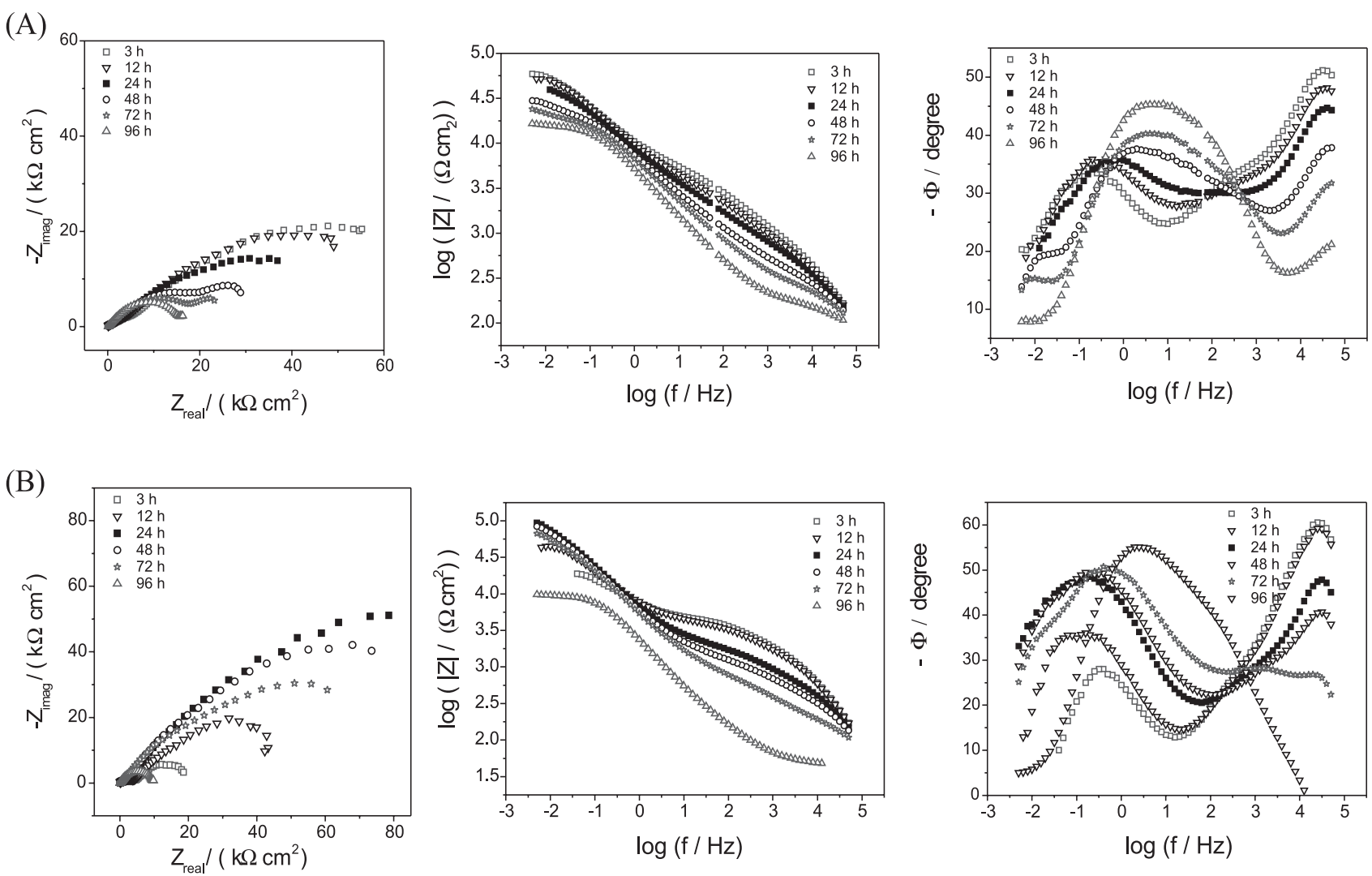

(C)
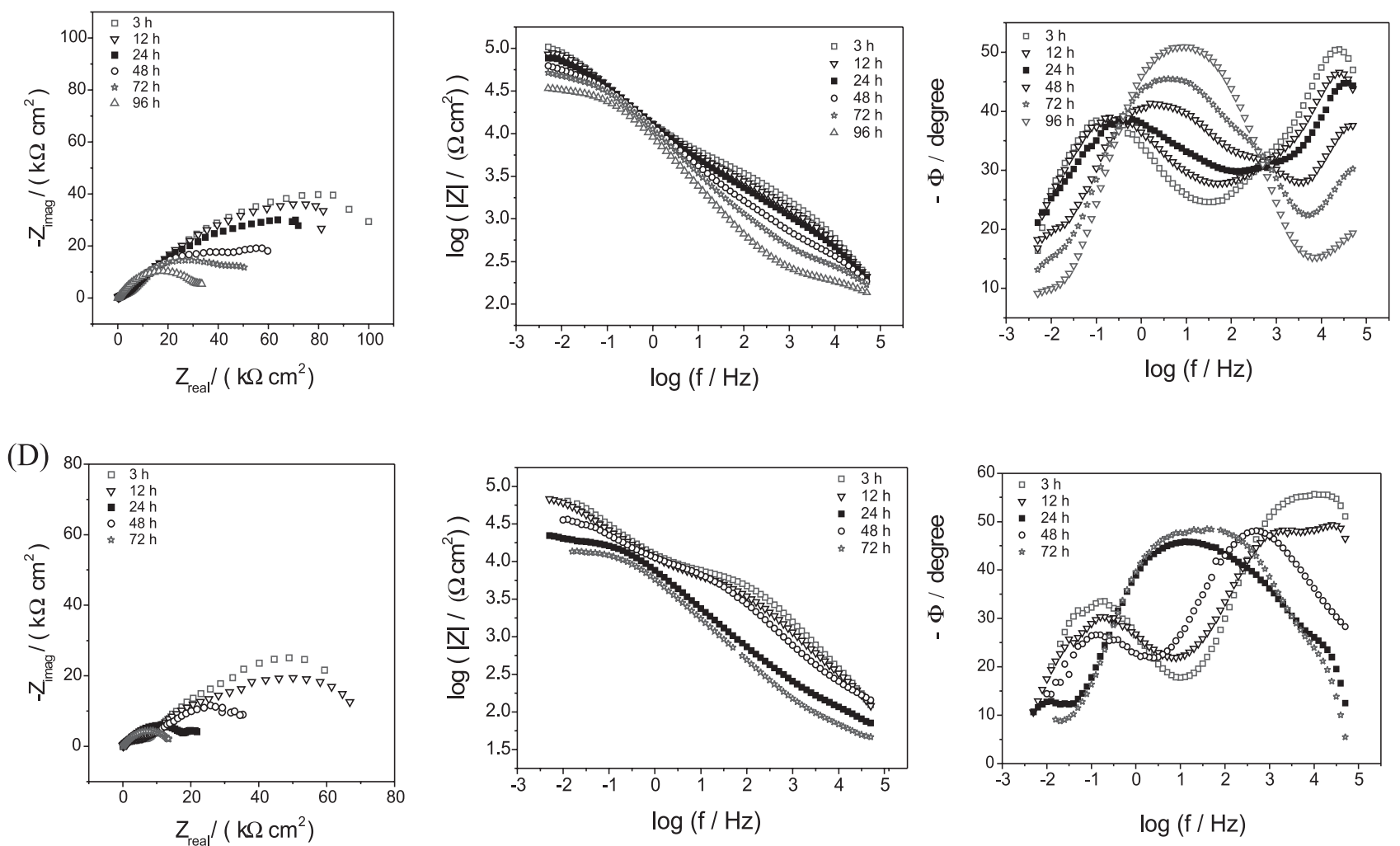

Figure 8. EIS diagrams for D150 series, Nyquist plots and $\log |\mathrm{Z}|$ and $-\phi v s$. $\log (\mathrm{f})$ Bode plots for (A) D50A (B) D150B, (C) D150C and (D) D150D samples obtained after $3,12,24,48,72$ and $96 \mathrm{~h}$ (not obtained to D150D) of immersion in $0.1 \mathrm{~mol} \mathrm{~L}^{-1} \mathrm{NaCl}_{\mathrm{solution}}$. 


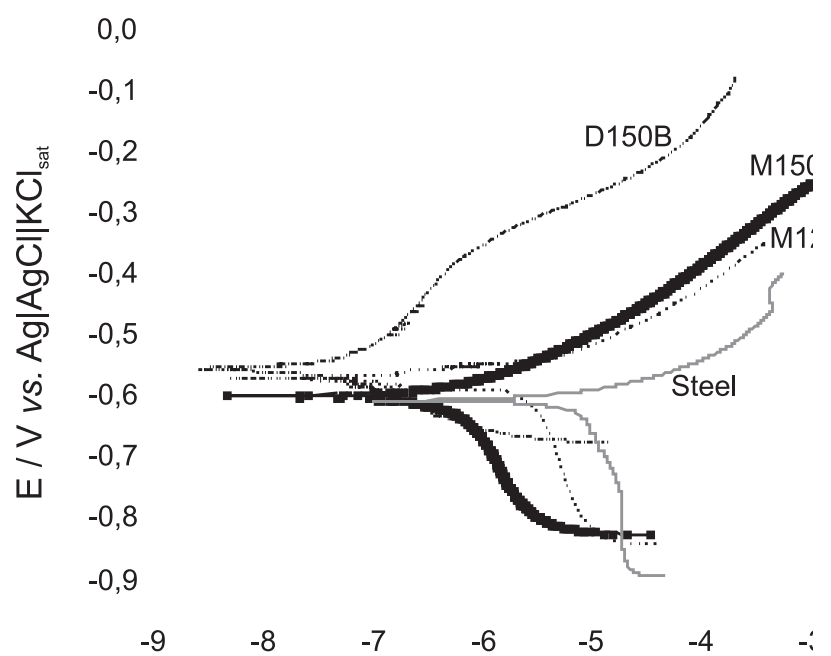

Figure 9. Polarization curves for (A) S120A, (B) S150A and (C) D150B samples obtained after 30 min of immersion in $0.1 \mathrm{~mol} \mathrm{~L}^{-1} \mathrm{NaCl}$ solution at $25^{\circ} \mathrm{C}$ and $\mathrm{v}=0.5 \mathrm{mV} \mathrm{s}^{-1}$.

series (S120A, S150A and D150B samples), comparing current density response at $-0.4 \mathrm{~V}$, for example, it is possible to observe that D150B sample presented a current density more than two orders of magnitude lower than S120A and S150A samples and three orders of magnitude lower than bare carbon steel substrate, indicating that the polarization measurements can be used to distinguish very good from very bad quality films. Films with similar characteristics present overlapped curves being difficult to interpret and make conclusions. EIS measurements made it possible to better distinguish between good and bad quality films because this technique is more sensitive than the polarization curves. But compared to carbon steel substrate, all samples presented a lower current density response and it represents a protection to substrate.

\section{Conclusions}

Temperature of the silane film cure process influences the corrosion protection of substrate. Silane single and double layer can supply protection to the substrate, but when a double layer is used, the corrosion resistance increases by one order of magnitude. Silane films when filled with $\mathrm{Cu}-\mathrm{Ph}$ provide improved corrosion resistance to the substrate. When a single layer was used, the optimum copper phthalocyanine concentration in the corresponding silane solution was $1 \times 10^{-4} \mathrm{~mol} \mathrm{~L}^{-1}$. Incorporation of an extra amount of $\mathrm{Cu}-\mathrm{Ph}$ in to BTSPA film seemed to degrade the corrosion performance of the film. When a double layer is prepared, the first layer can be filled with $5 \times 10^{-4}-1 \times 10^{-3} \mathrm{~mol} \mathrm{~L}^{-1}$ concentration of copper phthalocyanine.
EIS results indicated the BTSPA film heavily loaded with $\mathrm{Cu}-\mathrm{Ph}$ tends to prematurely degrade the film on carbon steel substrate. In double layer films it is possible to increase the $\mathrm{Cu}-\mathrm{Ph}$ concentration because the second layer close the defects caused by curing process in the first layer.

Incorporation of $\mathrm{Cu}-\mathrm{Ph}$ into the silane film showed a positive effect on the overall corrosion performance of the coated steel system, mainly for double layer films.

\section{Acknowledgments}

The authors are grateful to FAPESP-Fundação de Amparo à Pesquisa do Estado de São Paulo for the postdoctoral scholarship (Proc. no. 05/51851-4).

\section{References}

1. Subramanian, V.; MSc Dissertation, University of Cincinnati, Cincinnati, US, 1999.

2. Plueddemann, E. P.; Silane Coupling Agents, $1^{\text {st }}$ ed., Plenum Press: New York, 1982.

3. Montemor, M. F.; Simões, A. M.; Ferreira, M. G. S.; Williams, B.; Edwards, H.; Prog. Org. Coat. 2000, 38, 17.

4. Schaftinghen, T. V.; Pen, C. L.; Terryn, H.; Hörzenberger, F.; Electrochim. Acta 2004, 49, 2997.

5. Subramanian, V.; van Ooij, W. J.; Corrosion 1998, 54, 204.

6. Wapner, K.; Grundmeier, G.; Surf. Coat. Technol. 2005, 200, 100 .

7. Montemor, M. F.; Rosqvist, A.; Fargerholm, H.; Ferreira, M. G. S.; Prog. Org. Coat. 2004, 51, 188.

8. Cabral, A.; Duarte, R. G.; Montemor, M. F.; Zheludkevich, M. L.; Ferreira, M. G. S.; Corros. Sci. 2005, 47, 869.

9. Franquet, A.; Terryn, H.; Vereecken, J.; Thin Sol. Films 2003, $441,76$.

10. Zucchi, F.; Grassi, V.; Frignani, A.; Monticelli, C.; Trabanelli, G.; Surf. Coat. Technol. 2006, 200, 4136.

11. Franquet, A.; De Laet, J.; Schram, T.; Terryn, H.; Subramanian, V.; van Ooij, W. J.; Thin Sol. Films 2001, 384, 37.

12. Trabelsi, W.; Dhouibi, L.; Ferreira, M. G. S.; Zheludkevich, M. L.; Montemor, M. F.; Surf. Coat. Technol. 2006, 200, 4240.

13. Palanivel, V.; Huang, Y.; van Ooij, W. J.; Prog. Org. Coat. 2005, $53,153$.

14. Zhu, D.; van Ooij, W. J.; Corros. Sci. 2003, 45, 2177.

15. Ferreira, M. G. S.; Duarte, R. G.; Montemor, M. F.; Simões, A. M. P.; Electrochim. Acta 2004, 49, 2927.

16. Khramov, A. N.; Voevondin, N. N.; Balbyshev, V. N.; Mantz, R. A.; Thin Sol. Films. 2005, 483, 191.

17. Aoki, I. V.; Guedes, I. C.; Maranhão, S. L. A.; J. Appl. Electrochem. 2002, 32, 915.

18. Trabelsi, W.; Dhouibi, 1.; Triki, E.; Ferreira, M. G. S.; Montemor, M. F.; Surf. Coat. Technol. 2005, 192, 284. 
19. Brown, M. E.; Introduction to Thermal Analysis, Techniques and Applications, $2^{\text {nd }}$ ed., Kluwer Academic Publishers: New York, 2001.

20. Lever, A. B. P.; Adv. Inorg. Chem. Radiochem. 1965, 7, 27.

21. Maranhão, S. L. A.; Guedes, I. C.; Anaissi, F. J.; Toma, H. E.; Aoki, I. V.; Electrochim. Acta 2006, 52, 519.

22. Silverstein, R. M.; Webster, F. X.; Kiemle, D.; Spectrometric Identification of Organic Compounds, $7^{\text {th }}$ ed., John Wiley \& Sons: New York, 2005.

23. Stuart, B.; Modern Infrared Spectroscopy, $1^{\text {st }}$ ed., John Wiley \& Sons: New York, 1996.
24. van Ooij, W. J.; Zhu, D.; Palanivel, V.; Lamar, J. A.; Stacy, M.; Silicon Chem. 2006, 1-2, 11.

25. Hiemenez, P. C.; Rajagopalan, R.; Principles of Colloid and Surface Chemistry, $3^{\text {rd }}$ ed., Marcel Dekker: New York, 1997.

26. Lyklema, J.; van Leeuwen, H. P.; Fundamentals of Interface and Colloid Science, Elsevier Academic Press: The Netherlands, 1991.

Received: September 30, 2007

Web Release Date: April 29, 2008

FAPESP helped in meeting the publication costs of this article. 